\section{A systematic approach to evaluate the hygienic quality of feedstuffs for horses}

\author{
Josef Kamphues
}

Institute of Animal Nutrition, University of Veterinary Medicine Hannover, Foundation

\section{Introduction}

The Regulation (EC) No 183/2005 of January 12th 2005 containing requirements for feed hygiene shall apply as from January $1 \mathrm{st} 2006$. Although this regulation aims at food producing animals only its principles should be considered which were layed down to ensure a high level of protection of animal health in general. "Feed hygiene" means the measures and conditions necessary to control hazards and to ensure fitness for animal consumption of a feed, taking into account its intended use. Although in the Regulation (EC) No 183/2005 the different risks of biological, chemical and physical contaminations of feed are considered this contribution is focussed on biological/microbiological criteria of the quality of feedstuffs, i.e. on measures and efforts that can be used to characterize the hygienic quality of feeds for horses (including bedding materials like straw).

Hygienic quality of feeds: of special interest for veterinary practitioners

Field studies as well as investigations in laboratories on the quality of feedstuffs for horses (hay, straw, concentrates) are indicating a frequent occurrence of deviations in the hygienic quality of feeds and bedding material used in horse stables. Loads by mites and moulds (hay, straw, eventually cereals and complete feeds) are well to the fore, in a lower frequency a higher contamination by yeasts (silages, molassed oats, sometimes concentrates) or bacteria (especially in oats) gave rise to objection. Besides the negative effects of these loads on nutritive value and the palatability the first main risk - due to ingestion - lies in producing digestive disorders (enhanced gastrointestinal gas forming by yeasts and further gas producing microorganisms, reduced fibre digestion in the hind gut due to dysbiotic changes in the flora). Besides the effects of active germs detrimental influences of toxins produced by bacteria (for example Clostridium botulinum) or by different species of moulds (Claviceps purpurea, Fusarium, Aspergillus, Penicillium) should not be neglected.

In recent years further risks are considered more and more: during ingestion of loaded feedstuffs and roughage the respiratory tract of horses is exposed to mites, infectious microorganisms (risk of mycosis) and toxins. Furthermore, the quality of the air within stables is influenced negatively (dust containing fine fractions of feeds and bedding material). Therefore optimizing the conditions of feed production and storing (including the straw used as bedding material) is an essential for maintaining the health and performance of horses.

Criteria suitable to characterize the hygienic quality of feeds for horses

When an evaluation of the hygiene status of feeds is intended - for example in cases of gastrointestinal or respiratory tract disorders in horses - it is necessary to look at different kinds of loads in feeds (Tab. 1) that could affect animals' health, wellbeing and performance.

Tab 1 Kinds of loads in feedstuffs for horses (modified according Kamphues 1996).

\begin{tabular}{|c|c|c|}
\hline \begin{tabular}{|c|}
$\begin{array}{c}\text { contaminants / } \\
\text { load by }\end{array}$ \\
\end{tabular} & $\begin{array}{c}\text { Occurrence in feeds for horses } \\
\text { (examples) }\end{array}$ & $\begin{array}{l}\text { Effects in horses } \\
\text { (examples) }\end{array}$ \\
\hline - dirt / dust & $\begin{array}{l}\text { - chaff in uncleaned cereals } \\
\text { like oat, barley, concentrates } \\
\text { - soil / sand in / on hay, straw, } \\
\text { beets, carrots } \\
\text { - faeces and urine of rats, mice } \\
\text { (uncovered concentrates) }\end{array}$ & $\begin{array}{l}\text { impairment of respiratory tract } \\
\text { (mechanical irritation) } \\
\text { gastrointestinal disorders } \\
\text { ("sand colic") } \\
\text { exposition to pathogenous } \\
\text { bacteria like Salmonella }\end{array}$ \\
\hline $\begin{array}{r}\text { - pests / } \\
\text { insects }\end{array}$ & $\begin{array}{l}\text { - moths in / on concentrates, } \\
\text { cereals } \\
\text { - beetles in/on cereals, } \\
\text { concentrates, hay, straw } \\
\text { - mites in cereals, hay, straw }\end{array}$ & $\begin{array}{l}\text { reduced feed palatability and } \\
\text { lower feed intake } \\
\text { allergic reactions, cough } \\
\text { colic symptoms (?) }\end{array}$ \\
\hline $\begin{array}{l}\text { - moulds / } \\
\text { yeasts }\end{array}$ & $\begin{array}{l}\text { - epiphytic moulds (like } \\
\text { Fusarium) on cereals } \\
\text { - species indicating spoilage } \\
\text { (Aspergillus, Mucor) } \\
\text { - yeasts on silage, cereals, wet } \\
\text { concentrates, molassed cob }\end{array}$ & $\begin{array}{l}\text { intestinal dysbiosis (?) } \\
\text { altered flora composition } \\
\text { infection, mycosis } \\
\text { (i.e. guttural pouch mycosis) } \\
\text { enhanced intestinal gas } \\
\text { formation (esp. stomach) }\end{array}$ \\
\hline - bacteria & $\begin{array}{l}\text { - epiphytic bacteria on cereals } \\
\text { (like Flavobacterium) } \\
\text { - species indicating spoilage } \\
\text { (like Staphylococcus) } \\
\text { - pathogenous species like } \\
\text { Salmonella, Leptospira }\end{array}$ & $\begin{array}{l}\text { gastrointestinal dysbiosis } \\
\text { (disturbed flora composition) } \\
\text { gastrointestinal dysbiosis } \\
\text { (altered flora activity) } \\
\text { diarrhea, abortion (depend- } \\
\text { ing on species of bacteria) }\end{array}$ \\
\hline $\begin{array}{l}\text { - toxins of } \\
\text { micro- } \\
\text { organisms }\end{array}$ & $\begin{array}{l}\text { - mycotoxins (cereals, grass, } \\
\text { maize silage) } \\
\text { - endotoxins (from gram- } \\
\text { negative bacteria) } \\
\text { - exotoxins like botulism toxins }\end{array}$ & $\begin{array}{l}\text { mycotoxicosis (effects de- } \\
\text { pending on kind of toxin) } \\
\text { respiratory tract diseases } \\
\text { (irritation, sensitization) } \\
\text { intoxication }\end{array}$ \\
\hline
\end{tabular}

Conditions resulting in lacks of the hygienic quality

Whenever lacks in the hygienic quality of feedstuffs occur it is necessary to find out where and why those deviations could originate, in order to prevent and to avoid them in the future. The main factors - beginning at the level of primary production following operations like storing, transporting, mixing and offering the feed - that influence and determine the hygienic quality are the water content in the feed and the cleanliness in handling the feed (especially valid for the process of storing). Therefore it is recommended to consider these aspects when anamnestic information is gathered by veterinary practitioners.

An elevated water content in feeds might be caused by an insufficient dry matter content at harvesting (cereals, hay, straw), by resign on drying after the harvest (cereals) or by a secondary uptake of water (process of condensation). Furthermore it has to be emphasized that the dry matter content of all feeds continuously varies in relation to air humidity. This is the most important factor while feeds are stored for a longer period. 
In all processes of feed production, storing, transporting, mixing and offering the cleanliness has to be considered. Soil contamination, excrements of birds or rodents, remainders of old feeds can result in higher loads of microorganisms in feeds. Cleaning and disinfection (against pests, insects) is therefore necessary before new batches of feed are stored up. Special disposition for aerobe deterioration exists in feeding silages; within 1 or 2 days very high counts of yeasts can be observed which could not grow as long as anaerobe conditions existed.

\section{Measures recommended for evaluating the hygienic quality}

A systematical approach is necessary that allows an evaluation of feedstuffs' hygiene, including information gathered from different sources (Table 2).

Tab 2 Steps and measures that allow a judgement of the hygienic quality of feedstuffs (incl. straws as bedding material).

\begin{tabular}{|l|l|l|}
\hline & Step measures & intended information \\
\hline 1 & $\begin{array}{l}\text { anamnesis concerning the } \\
\text { horses' reactions }\end{array}$ & $\begin{array}{l}\text { peculiarities in producing, storing, handling } \\
\text { horses' owners / personnel) }\end{array}$ \\
\hline 2 & $\begin{array}{l}\text { sensual inspection (appea } \\
\text { rance, smell, texture) }\end{array}$ & $\begin{array}{l}\text { deviations in the appearance, smell, texture } \\
\text { (including different loads, s. Tab. 1) }\end{array}$ \\
\hline 3 & $\begin{array}{l}\text { estimation of the dry matter } \\
\text { content (and pH in silages) }\end{array}$ & $\begin{array}{l}\text { conditions for growth of pests, insects and } \\
\text { microorganisms (in silages: effects of pH!) }\end{array}$ \\
\hline 4 & $\begin{array}{l}\text { microbiological investigations } \\
\text { (laboratory analysis) }\end{array}$ & $\begin{array}{l}\text { kind and counts of moulds, yeasts and } \\
\text { bacteria (s. Tab. 3) }\end{array}$ \\
\hline 5 & $\begin{array}{l}\text { estimation of the LPS mass of } \\
\text { gram content }\end{array}$ & $\begin{array}{l}\text { negative bacteria (actual and earlier load, } \\
\text { independent of cultural growth) }\end{array}$ \\
\hline 6 & $\begin{array}{l}\text { estimation of the mycotoxin } \\
\text { content (laboratory analysis) }\end{array}$ & $\begin{array}{l}\text { kind and concentrations of different } \\
\text { mycotoxins (produced by Fusarium spp, } \\
\text { Aspergillus / Penicillium spp.) }\end{array}$ \\
\hline 7 & $\begin{array}{l}\text { feeding experiment } \\
\text { (at an institute) }\end{array}$ & $\begin{array}{l}\text { to reproduce reactions / symptoms that } \\
\text { were observed in the special case }\end{array}$ \\
\hline
\end{tabular}

'due to high expenses recommended for exceptionally interesting cases only, but eventually worth while because feeds' effects are tested comprehensively

Based on experiences in the last two decades and in cooperation of different institutes and laboratories in Germany a scheme was established (GEGFM 2002) that allows a scientifically based evaluation of the results achieved by standardized microbiological investigations (Tab. 3).

Tab 3 Characterization of microorganisms occurring on feedstuffs which are analyzed by microbiological cultural techniques (GEGFM 2002).

\begin{tabular}{|c|c|c|c|}
\hline $\begin{array}{l}\text { kind of micro- } \\
\text { organisms }\end{array}$ & $\begin{array}{l}\text { classification of the } \\
\text { microorganisms }\end{array}$ & $\begin{array}{c}\text { group } \\
\text { No }\end{array}$ & $\begin{array}{l}\text { Species that represent the group } \\
\text { number typically (examples only) }\end{array}$ \\
\hline \multirow{3}{*}{$\begin{array}{l}\text { aerobe } \\
\text { bacteria }\end{array}$} & feed-typical & 1 & $\begin{array}{l}\text { Flavobacterium } \\
\text { Pseudomonas }\end{array}$ \\
\hline & \multirow{2}{*}{$\begin{array}{l}\text { indicating spoilage } \\
\text { / deterioration }\end{array}$} & 2 & \begin{tabular}{|l|} 
Bacillus \\
Staphylococcus / Micrococcus
\end{tabular} \\
\hline & & 3 & Streptomyces spp. \\
\hline \multirow{3}{*}{$\begin{array}{l}\text { aerobe } \\
\text { moulds }\end{array}$} & feed-typical & 4 & $\begin{array}{l}\text { Verticillium } \\
\text { Acremonium } \\
\text { Fusarium } \\
\text { Aureobasidium }\end{array}$ \\
\hline & \multirow[t]{2}{*}{$\begin{array}{l}\text { indicating spoilage } \\
\text { / deterioration }\end{array}$} & 5 & $\begin{array}{l}\text { Aspergillus } \\
\text { Penicillium } \\
\text { Scopulariopsis } \\
\text { Wallemia }\end{array}$ \\
\hline & & 6 & Mucor spp. \\
\hline yeasts & indicating spoilage & 7 & all species \\
\hline
\end{tabular}

For all these microorganisms "normal counts" (= n.c.) in different ingredients and complete feeds were set up. Depending on the feed (and its preparation), and the species of the microorganisms the normal counts per gram feed differ markedly (Tab. 4).

Tab 4 Upper "normal counts" of different groups of microorganisms in concentrates used in horse feeding (only examples; based on recommendations of the German Experts Group of Feed Microbiologists, 2002).

\begin{tabular}{|l|c|c|c||c|c|c|c|}
\hline \multirow{3}{*}{ feedstuffs } & \multicolumn{7}{|c|}{ group number } \\
\cline { 2 - 8 } & $\mathbf{1}$ & $\mathbf{2}$ & $\mathbf{3}$ & $\mathbf{4}$ & $\mathbf{5}$ & $\mathbf{6}$ & $\mathbf{7}$ \\
\hline & \multicolumn{3}{|c||}{ counts in $10^{6} / \mathbf{g}$} & \multicolumn{4}{c|}{ counts in $10^{3} / \mathbf{g}$} \\
\hline oats & 15 & 1 & 0.1 & 70 & 30 & 2 & 50 \\
\hline barley & 8 & 1 & 0.1 & 60 & 30 & 2 & 50 \\
\hline mixed feeds & & & & & & & \\
\hline - unpelleted & 5 & 0.5 & 0.1 & 30 & 20 & 5 & 50 \\
\hline - pelleted & 0.5 & 0.1 & 0.05 & 5 & 5 & 1 & 5 \\
\hline
\end{tabular}

Results of the microbiological investigations should be compared to the "normal counts" of the ingredients or mixed feeds considering the group to which the species belong to (Tab. 5).

Tab 5 Grades in the hygienic quality of feedstuffs related to the results of microbiological investigations (GEGFM 2002).

\begin{tabular}{|c|c|c|}
\hline $\begin{array}{c}\text { quality } \\
\text { grade }\end{array}$ & $\begin{array}{c}\text { results of the microbiological } \\
\text { investigation (n.c. }=\text { normal counts) }\end{array}$ & interpretation \\
\hline $\mathrm{I}$ & all 7 groups': values $<$ n.c. & "no reason for objection" \\
\hline $\mathrm{I}$ & in at least 1 group $>$ n.c. $<5 x$ n.c. & "slightly increased load" \\
\hline$I \mathrm{II}^{2}$ & in at least 1 group $>5 x$ n.c. $\leq 10 x$ n.c. & "markedly increased load" \\
\hline $\mathrm{IV}^{2}$ & in at least 1 group $>10 x$ n.c. & $\begin{array}{c}\text { "indicating spoilage" / } \\
\text { "advanced spoilage" }\end{array}$ \\
\hline
\end{tabular}

${ }^{1}$ table 3, where representative species of the groups are discribed

2 further investigations concerning mycotoxine contents are necessary

In the case that higher counts of moulds are found that are able to produce mycotoxins it is recommended to test the feed on its mycotoxin content. In contrast to feeds for food producing animals up to now it is not possible to present upper limits of tolerable mycotoxin levels but the values established for young pigs might be used.

Tab 6 Field relevant moulds and mycotoxins in feedstuffs for horses (modified according Kamphues 1996).

\begin{tabular}{|l|l|l|l|}
\hline $\begin{array}{l}\text { moulds } \\
\text { (species) }\end{array}$ & mycotoxins & occurrence & effects in horses \\
\hline Claviceps & ergot-alcaloides & $\begin{array}{l}\text { grass, hay (?), } \\
\text { ray-/wheat-bran }\end{array}$ & $\begin{array}{l}\text { abortion, due to prolactin } \\
\text { antagonism agalactation }\end{array}$ \\
\hline Aspergillus & aflatoxins & $\begin{array}{l}\text { byproducts of oil con- } \\
\text { taining seeds, maize }\end{array}$ & $\begin{array}{l}\text { liver metabolism } \downarrow \text {, } \\
\text { immunolog. reactions } \downarrow\end{array}$ \\
\hline $\begin{array}{l}\text { Penicillium } \\
\text { Aspergillus }\end{array}$ & ochratoxins & $\begin{array}{l}\text { cereals (and further } \\
\text { concentrates) }\end{array}$ & $\begin{array}{l}\text { kidney disorders } \\
\text { (polydipsia and polyuria) }\end{array}$ \\
\hline Fusarium & zearalenone & $\begin{array}{l}\text { cereals, maize silage, } \\
\text { maize byproducts, straw } \\
\text { (beddingmat. !) }\end{array}$ & $\begin{array}{l}\text { reduced fertility, hyper- } \\
\text { estrogenism, disturbed } \\
\text { reproductive cycle }\end{array}$ \\
\cline { 2 - 5 } & deoxinivalenol & $\begin{array}{l}\text { cereals and byproducts } \\
\text { of milling industry }\end{array}$ & $\begin{array}{l}\text { reduced feed intake, } \\
\text { intestinal disorders }\end{array}$ \\
\cline { 2 - 5 } & fumonisine & $\begin{array}{l}\text { cereals and byproducts } \\
\text { of milling industry }\end{array}$ & $\begin{array}{l}\text { Equine Leuco- } \\
\text { encephalomalacia }\end{array}$ \\
\hline
\end{tabular}

The occurrence of mycotoxins in feedstuffs for horses is depending on the species of moulds on the feed and various environmental conditions (temperature, humidity) and is related to the area where the feeds are growing or produced. Therefore the occurence of several mycotoxins differs markedly between regions and countries of the world. In North America for example Acremonium infected grass resulted repeatedly - due to the load by toxins - in reproductive disorders of mares (prolonged gestation, agalactation, retentio secundinarum), that are not observed in Europe up to now. 
Due to the international trade of ingredients that are used in producing mixed feeds for horses there is also a trend for a world wide spread of mycotoxins that has to be considered when the hygiene of feeds is on debate.

For roughages and silages it is not possible up to now to present "normal counts" of microorganisms as presented in table 4 for concentrates but the classification might be identical or at least comparable.

In general counts of moulds show slightly higher values in roughages (hay, straws) than in concentrates, but counts of $>$ $10^{5} / \mathrm{g}$ hay or straw are conspicuous, counts of $10^{6} / \mathrm{g}$ should be objected due to the fact that under these conditions in a high frequency further lacks in the hygienic quality can be found (like increased load by insects, mites, dust and so on). In silages not rarely higher counts of yeast are found, values $<10^{4}$ should not be objected, but values of $10^{5}-10^{6} / \mathrm{g}$ silage are indicating advanced processes of aerobe deterioration (risk of increased production of gas within the gastrointestinal tract, eventually resulting in colic symptoms).

In some laboratories lipopolysaccharides (LPS) contents in feedstuffs are estimated when the hygienic status of feeds is on debate. The LPS content indicates (indirectly) the mass of gram-negative bacteria, therefore it is a helpful supplementary information when the hygiene status has to be characterized (Tab. 7).

Tab 7 LPS contents $(\mu \mathrm{g} / \mathrm{g})$ in feeds for horses (Kamphues 1996).

\begin{tabular}{|l|c|c|c|}
\hline \multicolumn{1}{|c|}{ feeds } & normal values & increased load & $\begin{array}{c}\text { values indicating } \\
\text { a marked load }\end{array}$ \\
\hline oats & $<20$ & $20-50$ & $>50$ \\
\hline concentrates & $<10$ & $10-20$ & $>20$ \\
\hline hay / straw & $<35$ & $35-75$ & $>100$ \\
\hline
\end{tabular}

\section{Conclusion}

Although an intensive evaluation of the hygiene status of feedstuffs is mostly done when health problems occur that could be caused by corresponding lacks it is recommended to veterinary practitioners to consider those aspects in the daily work to gather own experiences, especially concerning the sensual / visual inspection of feedstuffs and bedding material that are actually in use. Especially the storing conditions of feedstuffs and straw earn the special interest of veterinarians because these conditions mainly predispose for lacks in the hygienic quality of feedstuffs.

Recommendations for optimizing the quality of feeds and feeding are indicating the prophylactic aims of veterinary efforts and activities. The more these aspects are considered the more the primary goal of the new EU regulation No $183 / 2005$ is achieved: "Feed safety".

\section{References}

Baver J. and Hörmannsdorfer S. (2000): Bakterien in Futtermitteln, Potenzielle Schadorganismen und Stoffe in Futtermitteln sowie in tierischen Fäkalien, Sachstandsbericht, Mitteilung 4, DFG, WileyVCH, Weinheim 56-164
Baver J., Schneweiss I. and Hörmannsdorfer S. (2000): Pilze und deren Stoffwechselprodukte in Futtermitteln. Potenzielle Schadorganismen und Stoffe in Futtermitteln sowie in tierischen Fäkalien, Sachstandsbericht, Mitteilung 4, DFG, Wiley-VCH, Weinheim, 165-217

Coenen M. and Kienzle E. (1992): Beobachtungen zur hygienischen Beschaffenheit von Futtermitteln für Pferde in der tierärztlichen Ernährungsberatung. Sonderheft Pferdeheilkunde 8, 209-212

GEGFM (2002): German Experts Group of Feed Microbiologists; Arbeitskreis "Futtermikrobiologie" der Fachgruppe VI der VDLUFA). Entwurf für ein Orientierungsschema zur Auswertung der Ergebnisse mikrobiologischer Untersuchungen zwecks Beurteilung von Futtermitteln, $\S 7$ (3) Futtermittelgesetz, Stand 12.12.2002

Jaeckel S. (1995): Untersuchungen zum Nachweis von Aspergillen und Penicillien in Futtermitteln anhand ihrer extrazellulären Polysaccharide mittels eines Sandwich-Enzymimmunoassays. Diss. med. vet., Hannover, 1995.

Kamphues J. (1986): Lipopolysaccharide in Futtermitteln - mögliche Bedeutung, Bestimmung und Gehalte. Übers. Tierernährg. 14, 131-156

Kamphues J., Amtsberg G. and Klarmann D. (1989): Feinanteile und Staub in Futtermitteln - quantitative und qualitative (Pilze, Bakterien und Lipopolysaccharide) Aspekte. Berl. Münch. Tierärztl. Wschr. $102,418-421$

Kamphues J., Fimmen H., Küstermann S. and Meyer H. (1991): Lipopolysaccharides in feedstuffs for horses. Equine Vet. Sci. 11, 36-41

Kamphues J. und Schulze-Becking M. (1992): Milben in Futtermitteln - Vorkommen, Effekte, Bewertung. Übers. Tierernährg. 20, 1-38

Kamphues J. (1993): Futter und Fütterung - Beziehungen zur Gesundheit des Atmungstraktes. Mh. Vet.-Med. 48, 1993, 45-47.

Kamphues J. (1996): Risiken durch Mängel in der hygienischen Beschaffenheit von Futtermitteln für Pferde. Pferdeheilkde. 12, 326-332

Kamphues J. and Reichmuth C. (2000): Vorratsschädlinge in Futtermitteln. Potenzielle Schadorganismen und Stoffe in Futtermitteln sowie in tierischen Fäkalien, Sachstandsbericht, Mitteilung 4, DFG, Wiley-VCH, Weinheim, 238-284

Kamphues J., Coenen M., Kienzle E., Pallauf J., Simon O. and Zentek J. (2004): Supplemente zu Vorlesungen und Übungen in der Tierernährung, 10. Aufl., Schaper Verlag Alfeld

Küstermann S. (1989): Eine Feldstudie zum Hygienestatus von Pferdefuttermitteln unter besonderer Berücksichtigung des Lipopolysaccharidgehaltes. Diss. med. vet., Hannover

Müller H. M., Reimann J., Schwadorf K. and Thöni H. (1993): Zur Bewertung des Ergosteringehaltes von Futtermitteln. Kongreßband, 105. VDLUFA-Kongreß, Hamburg, 401-404

N.N. (2005): Regulation (EC) No 183 / 2005 of the Eurpean Parliament and of the Council of January 12th 2005 laying down requirements for feed hygiene, Official Journal of the European Union, Annex V of February 8th 2005

Rade C. and Kamphues J. (1999): Zur Bedeutung von Futter und Fütterung für die Gesundheit des Atmungstraktes von Tieren sowie von Menschen in der Tierbetreuung. Übers. Tierernährg. 27, 65121 